\title{
Ecological Structure of the Pelagic Seabird Community in the Benguela Current Region*
}

\author{
R. W. Abrams and A. M. Griffiths \\ FitzPatrick Institute, University of Cape Town, Rondebosch 7700, South Africa
}

\begin{abstract}
The distribution of pelagic seabirds off the west coast of southern Africa 15 analysed according to trophic guilds. Distribution of the birds is not random. At any given observation station one guild dominates the seabird assemblage. Piscivores and squid-eaters account for the bulk of avian abundance and biomass, the remainder being planktivores and omnivores. Intraguild competition for food apparently is reduced by interspecific differences in foraging behaviour and temporal separation A winter increase in avian species richness and diversity, and abundance and biomass, is supported by a seasonal increase in productivity. Correlations of seabird indices with oceanographic and meteorological parameters are poor This indicates that local seabird distribution is mainly a function of the availability of prey and the species' attributes for locating and capturing prey. However, subsets of parameters for water masses and weather correlate with seabird distribution.
\end{abstract}

\section{INTRODUCTION}

It is generally accepted that biological productivity in the pelagic environment can be correlated broadly with water masses characterized by temperature, salinity and suspended matter (Sverdrup et al., 1942; Emery et al., 1973). However, only a few attempts have been made to establish statistically-sound correlations between water masses, productivity and the distribution of pelagic seabirds (Pocklington, 1979), for assessing the value of seabirds as environmental predictors across wide oceanic zones.

This paper analyses the pelagic avifauna of the southern sector of the Benguela Current region, along the west coast of southern Africa, in terms of its diversity in relation to environmental features. More particularly, the question addressed in a preliminary analysis is: to what extent is the distribution and abundance of pelagic seabirds affected by measurable oceanographic and meteorological features? Moreover, the analysis identifies broad ecological and behavioural properties which affect avian distribution. The analysis was performed as part of a pilot study for developing deterministic models which could be useful generally in assessments of marine productivity and resources in the Southern Ocean.

\footnotetext{
- This paper constitutes part of the commemoration of the 21 st anniversary of the establishment of the Percy FitzPatrick Institute of African Ornithology
}

\section{STUDY AREA}

The principal water mass associated with the continental shelf in the study area (Fig. 1) consists of the Benguela Current upwelling system, comprising water which rises from ca. $300 \mathrm{~m}$ depth (Hart and Currie, 1960). Temperature, salinity and productivity in the principal water mass fluctuate seasonally (Emery et al. 1973); whereas the geographical orientation of the system is relatively constant throughout the year, the centre of upwelling and thus maximal productivity shifts longitudinally $100-170 \mathrm{~km}$ between summer and winter (Hart and Currie, 1960). The western boundary of the Benguela Current water mass coincides with an offshore divergence belt, an area of upwelling dissociated from the inshore system of upwelling, which occurs at the interface between the central South Atlantic surface water mass and the south-western African continental water mass (Bang, 1971). The study area extended from 2 to $335 \mathrm{~km}$ offshore, corresponding to Kessel's (1979) inner front (inshore waters), to the shelf-break front (shelf edge and slope) and embraces depths between 30 and $400 \mathrm{~m}$. Air temperatures, water temperatures, and salinities typical of an average year in this sub-tropical zone are $10^{\circ}-27^{\circ} \mathrm{C}$, $9^{\circ}-22^{\circ} \mathrm{C}$ and $34-36 \% \mathrm{~S}$ respectively (Sverdrup et al. 1942).

The Benguela Current upwelling system is highly productive (Cushing, 1971) and supports abundant populations of pelagic seabirds (Summerhayes et al., 


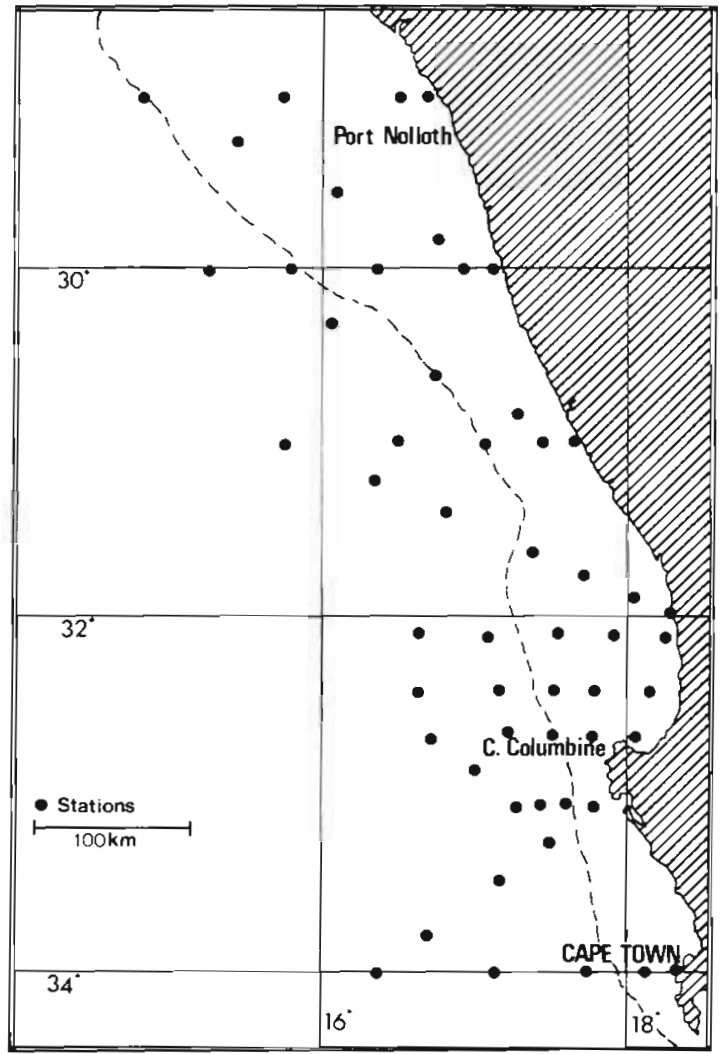

Fig. 1. Southern sector of Benguela Current region. Broken line traces the edge of the continental shelf; dots represent cruise stations occupied by R. S. 'Africana II' during $1950-1953$

1974). The study area is visited by many Southern Ocean seabirds during their non-breeding phases (Brooke, in press). This, as well as the similarities in temperature and salinity between the two regions (Emery et al., 1973), allows the study area to be regarded as a northern extension of the Southern Ocean ecosystem.

\section{MATERIAL AND METHODS}

From November 1950 to June 1953 the South African Government Research Vessel 'Africana II' made monthly survey cruises off the west coast of South Africa (Marchand, 1952). Standard seabird watches were made by $\mathrm{Cdr} A$. Thomas (for details see Cooper and Dowle, 1976), and physical oceanographic and meteorological data were obtained at the cruise stations shown in Figure 1. All birds seen were recorded with the aid of $8 \times$ binoculars from the ship's bridge (10 $\mathrm{m}$ above sea level), $15 \mathrm{~min}$ after the ship stopped at, and just before the ship departed from, each station. Additional species seen at any other time while the ship was on station were noted
Analyses of the basic data included 15 dependent variables and 8 independent variables for multivariate correlations. The dependent variables are: bird species richness (BSR), Shannon-Wiener index (BSD $=\mathrm{H}^{1}=$ - $p_{\mathrm{i}} \log P_{1}$ where $p$ is the proportion of the $i$ th species in the community of a particular area), total number (abundance) and total (live-weight) biomass of birds, and the numbers of individual birds in each of four food type and seven feeding method guilds (Appendix 1 contains the currently accepted trophic classification of species and their weights). The independent variables are: barometric pressure, water depth, distance from shore, surface salinity, surface-water temperature, air temperature, and wind and wave strengths.

\section{RESULTS}

\section{Seasonal Variation in Seabird Occurrence}

In the southern sector of the Benguela Current region, the pelagic avifauna characteristically is represented by 8 species and approximately 100 individuals at an 'average' observation station during the austral winter, when seabird communities are most diverse (Figs 2 and 3 ). The marked decline in diversity and biomass of the avifauna concomitant with the onset of spring is a reflection of emigration by those seasonal visitors which breed mainly in the subAntarctic region (Cooper and Dowle, 1976; Brooke, in press). During their sojourn in the Benguela Current region these species apparently subsist chiefly on fish and squid (Figs 4 and 5) which approach maximum abundance in winter, following the annual build up of prey stocks, resulting from enhanced productivity associated with upwelling of nutrients during spring and summer (Hart and Currie, 1960; Emery et al., 1973). Omnivorous birds and those feeding on plankton are generally least abundant in winter (Figs 6 and 7); and they constitute the smallest component of the avian community.

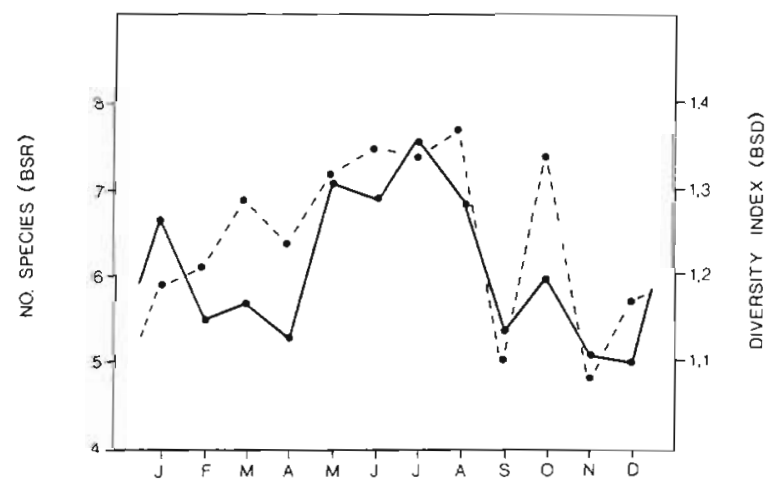

Fig. 2. Mean monthly species richness (continuous line) and diversity (Shannon - Wiener index; broken line) of seabird assemblages per observation station in the southern sector of the Benguela Current region 


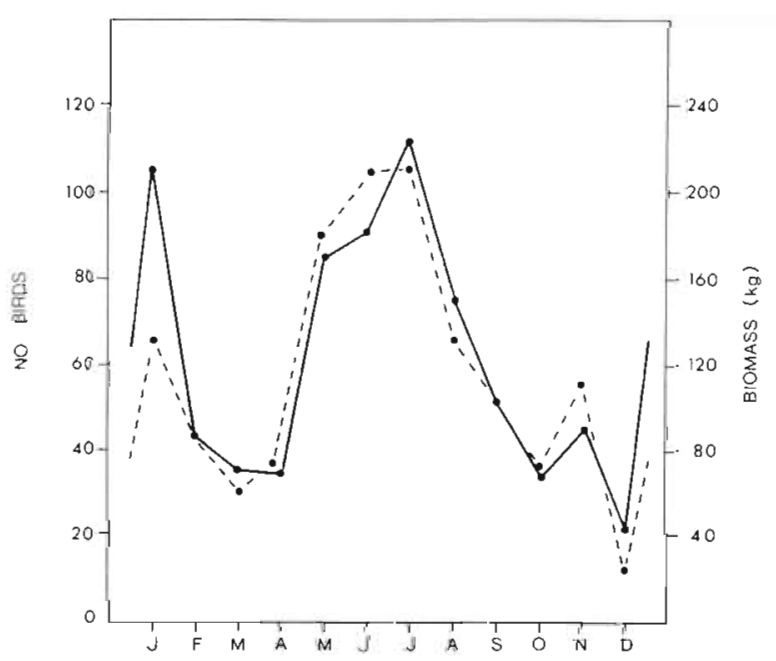

Fig. 3. Mean monthly abundance (numbers of individuals; continuous line) and biomass (broken line) of seabird assemblages per observation station in the southern sector of the Benguela Current region

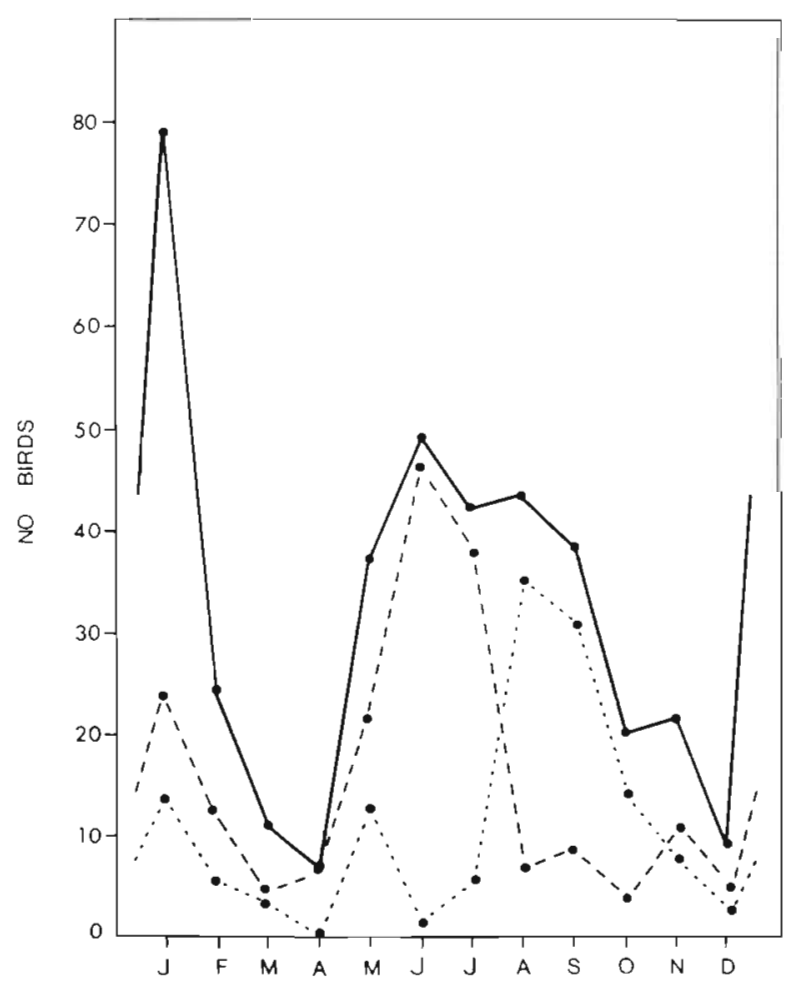

Fig. 4. Mean monthly abundance (numbers of individuals) of all piscivores (continuous line), plunge feeders (broken line) and pursuit-plungers and divers (dotted line) in seabird assemblages per observation station in the southern sector of the Benguela Current region

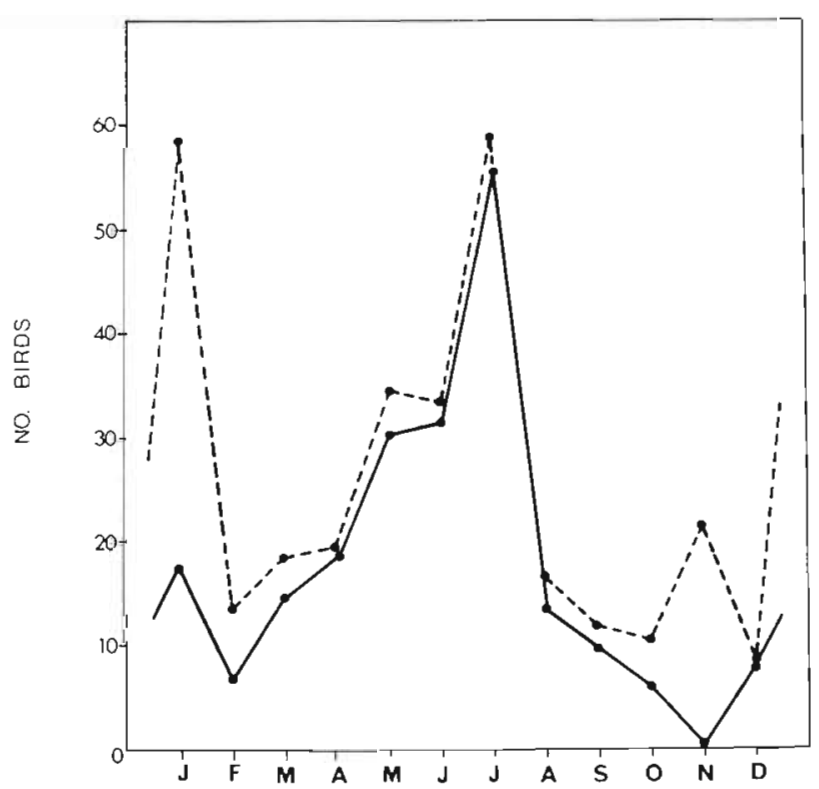

Fig. 5. Mean monthly abundance (number of individuals) of all squid-eaters (continuous line) and surface seizers/scavengers (broken line) in seabird assemblages per observation station in the southern sector of the Benguela Current region

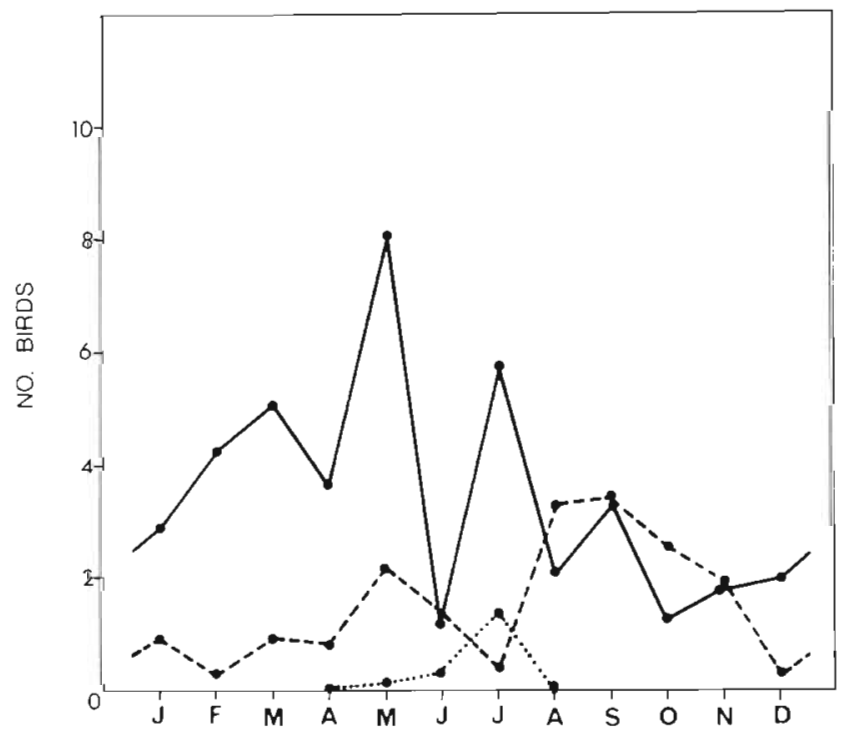

Fig. 6. Mean monthly abundance (numbers of individuals) of all plankton-eaters (broken line), dipping/pattering feeders (continuous line) and surface-filter feeders (dotted line) in seabird assemblages per observation station in the southern sector of the Benguela Current region

\section{Correlations Between Seabirds and Environmental Features}

We were unable to establish strong correlations of seabird species richness (BSR), diversity (BSD), abundance and biomass with individual oceanic or 


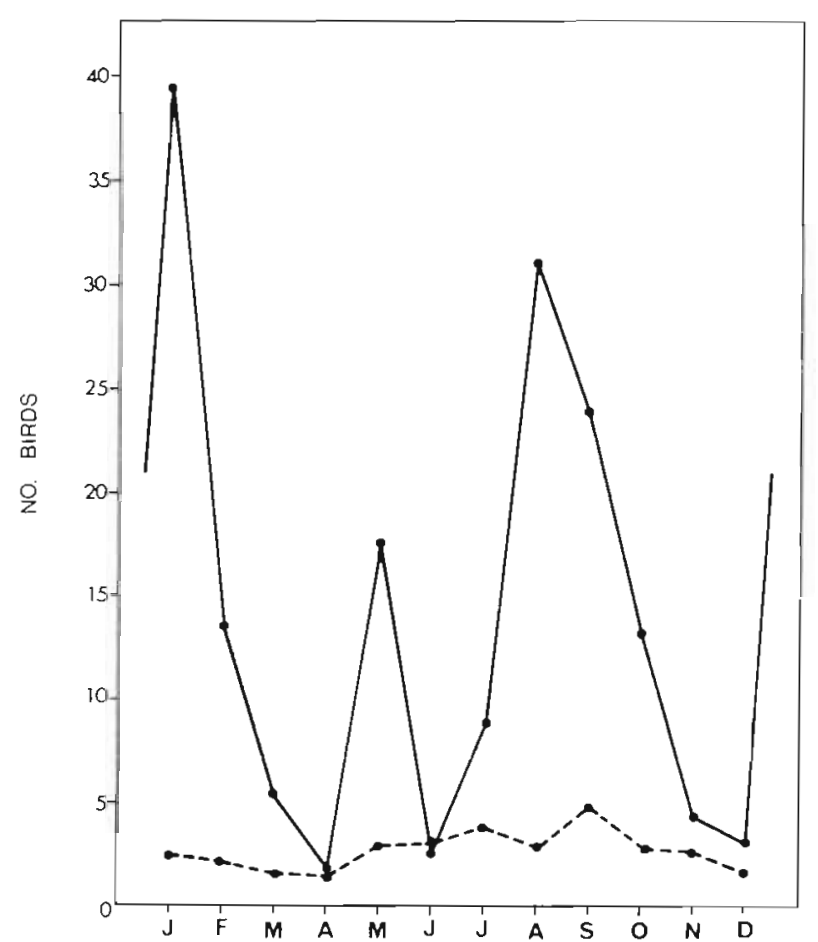

Fig. 7. Mean monthly abundance (numbers of individuals) of all omnivores (continuous line) and pirates (broken line) in seabird assemblages per observation station in the southern Benguela Current region

meteorological parameters. However, because seabirds might recognize, and respond to, subsets of environmental cues, we employed principal factor analysis which identified two subsets of abiotic data, water mass $\left(F_{1}\left(\lambda_{1}\right)=3.045\right)$ and weather $\left(F_{2}\left(\lambda_{2}\right)=\right.$ 1.716), for correlation with seabird distribution. Water temperature, distance from shore, salinity, air temperature, and depth (in descending order of influence) define water mass and significantly affect avian distribution more than any other subset of physical parameters (Table 1). Weather, as indexed by wind force and sea state (highly correlated with each other, $r=0.884$ ), also affects seabird distribution, albeit weakly Although Table 1 includes regressions which are significant by the F-statistic, all of the $\mathrm{R}^{2}$ values are very low. Nevertheless, it is notable that in all cases BSD shows at least some covariance with water mass and weather.

\section{Trophic Relationships}

The ecological structure of the pelagic avian community of the Benguela Current region is examined most meaningfully in terms of the birds food type and feeding method guilds (Landres and MacMahon, 1980), as opposed to discussing the species individually. Thus, piscivorous species contribute most to overall seabird abundance and biomass, closely followed by squid-eaters; omnivores and planktivores contribute least (Table 2). However, omnivores and planktivores correlate best with BSR and BSC, indicating that relatively few species (piscivores or squid-eaters) account for the bulk of the abundance and biomass of birds in the community.

Species which obtain their food by plunge diving contribute most to overall seabird biomass, whereas those classified as surface-seizers/scavengers account for most individuals (Table 2). Filter and bottom-feeders contribute least to either total avian biomass or abundance (Table 2). Good correlations in abundance occur between: surface-seizers/scavengers and squideaters; plungers and pursuit plungers/divers and piscivores; and, pirates and omnivores (Table 3).

Table 1 Coefficients of determination $\left(R^{2}\right)$ for statistically significant (F-statistic) relationships of water mass (Factor 1) and weather (Factor 2) with species richness (BSR), diversity (BSD), abundance (number of individuals) and biomass of seabird assemblages in the southern sector of the Benguela Current region

\begin{tabular}{|c|c|c|c|c|}
\hline & \multicolumn{2}{|c|}{ Water mass } & \multicolumn{2}{|c|}{ Weather } \\
\hline & $\mathrm{R}^{2}$ & $\begin{array}{c}\text { Significance level } \\
\text { (670 df) }\end{array}$ & $R^{2}$ & $\begin{array}{c}\text { Significance level } \\
\text { (671 df) }\end{array}$ \\
\hline \multicolumn{5}{|l|}{ All species } \\
\hline BSD & .051 & .0000 & .026 & .0000 \\
\hline Abundance & .037 & .0000 & .017 & .0008 \\
\hline Biomass & .026 & .0002 & .012 & .0045 \\
\hline \multicolumn{5}{|l|}{ Diomedeidae } \\
\hline BSR & .098 & .0000 & .028 & .0000 \\
\hline $\mathrm{BSD}$ & .075 & .0000 & .016 & .0012 \\
\hline Biomass & .033 & .0000 & .015 & .0017 \\
\hline \multicolumn{5}{|l|}{ Procellariidae } \\
\hline BSR & .067 & .0000 & .039 & .0000 \\
\hline $\mathrm{BSD}$ & .082 & .0000 & .053 & .0000 \\
\hline
\end{tabular}


Table 2. Coeficients of correlation ( $r$ ) between species richness (BSR), diversity (BSD), abundance (number of individuals) and biomass, and food-type and feeding-method groups in seabird assemblages in the southern sector of the Benguela Curent region. The values italics indicate important relationship affecting community structure

\begin{tabular}{|c|c|c|c|c|}
\hline Food type & BSR & BSD & Abundance & Biomass \\
\hline Plankton & .313 & .210 & 147 & 104 \\
\hline Cephalopods & .261 & -.038 & .625 & .539 \\
\hline Fish & 194 & -.270 & .839 & .810 \\
\hline Mixed & .347 & 129 & .275 & .261 \\
\hline \multicolumn{5}{|l|}{ Feeding method } \\
\hline Surface-seizes'scavengers & .274 & -.078 & 714 & .499 \\
\hline Surface filtering & .062 & .033 & -.008 & -.014 \\
\hline Plunging & 147 & -.244 & .642 & 792 \\
\hline Pursuit plunging/diving & 118 & -.124 & .515 & 478 \\
\hline Dipping/pattering & .277 & .171 & 164 & 120 \\
\hline Piracy & .324 & 123 & .257 & .238 \\
\hline Bottom feeding & .023 & -.020 & .059 & -.019 \\
\hline
\end{tabular}

Table 3. Coefficients of correlation ( $\mathrm{r}$ ) between food-type and feeding-method groups in seabird assemblages in the southern sector of the Benguela Current region. The values in italics indicate which groups together define trophic guilds

\begin{tabular}{|c|c|c|c|c|}
\hline \multirow[t]{2}{*}{ Feeding method } & \multicolumn{4}{|c|}{ Food } \\
\hline & Plankton & Cephalopods & Fish & Mixed \\
\hline Surface-seizing/scavenging & 148 & .855 & .322 & 125 \\
\hline Surface filtering & 219 & -.011 & -.022 & .019 \\
\hline Plunging & .000 & 106 & 745 & 202 \\
\hline Pursuit plunging/diving & -.022 & .084 & 602 & 116 \\
\hline Dipping/pattering & .952 & 174 & .007 & 125 \\
\hline Piracy & 103 & 132 & 183 & 989 \\
\hline Bottom feeding & -.037 & -.024 & .096 & .000 \\
\hline
\end{tabular}

There are no significant correlations of spatial occurrence between birds taking either different food (Table 4) or feeding by different methods (Table 5). There is a clear inshore-offshore separation between fish-eating and squid-eating birds (Fig. 8), and there is additional evidence (Fig. 9) for a seasonal latitudinal shift in the area of maximum avian biomass that presumably is a response to a similar shift in general marine productivity in the Benguela Current region (Emery et al., 1973).

The piscivore guild embraces mainly sub-surface feeders, including the permanently resident cormorants, the gannet Morus capensis and the jackass penguin Spheniscus demersus, but also contains seasonal visitors in the form of terns and shearwaters. These birds are primarily plungers and pursuit plungers/ divers, whereas the squid-feeders obtain their prey on the surface of the sea (Table 3 ). The squid-eaters are represented chiefly by procellariiform visitors from breeding stations in the Southern Ocean (Watson, 1975; Summerhayes, 1976). The omnivorous species are also surface feeders, but they obtain their food mainly through scavenging and kleptoparasitism (Table 3). Gulls and skuas account for the bulk of the omnivore guild and, since they frequently are present in mixed-species feeding assemblages, they strongly influence variation in BSR (Table 2). Prions, stormpetrels and the pintado petrel Daption capense are prominent in the plankton-eating guild, employing dipping and pattering feeding behaviour. This guild shows the most positive correlation trends with BSD (Table 2), probably reflecting the dense flocks of prions and pintado petrels which are common in the Benguela Current region.

Table 4. Coefficients of correlation ( $r$ ) between food-type groups in seabird assemblages in the southern sector of the Benguela Current region

\begin{tabular}{|lrcr|}
\hline Food type & Plankton & Cephalopods & Fish \\
\cline { 1 - 2 } Cephalopods & 176 & 1.000 & \\
Fish & -.020 & 105 & 1.000 \\
Mixed & .104 & 130 & .207 \\
\hline
\end{tabular}




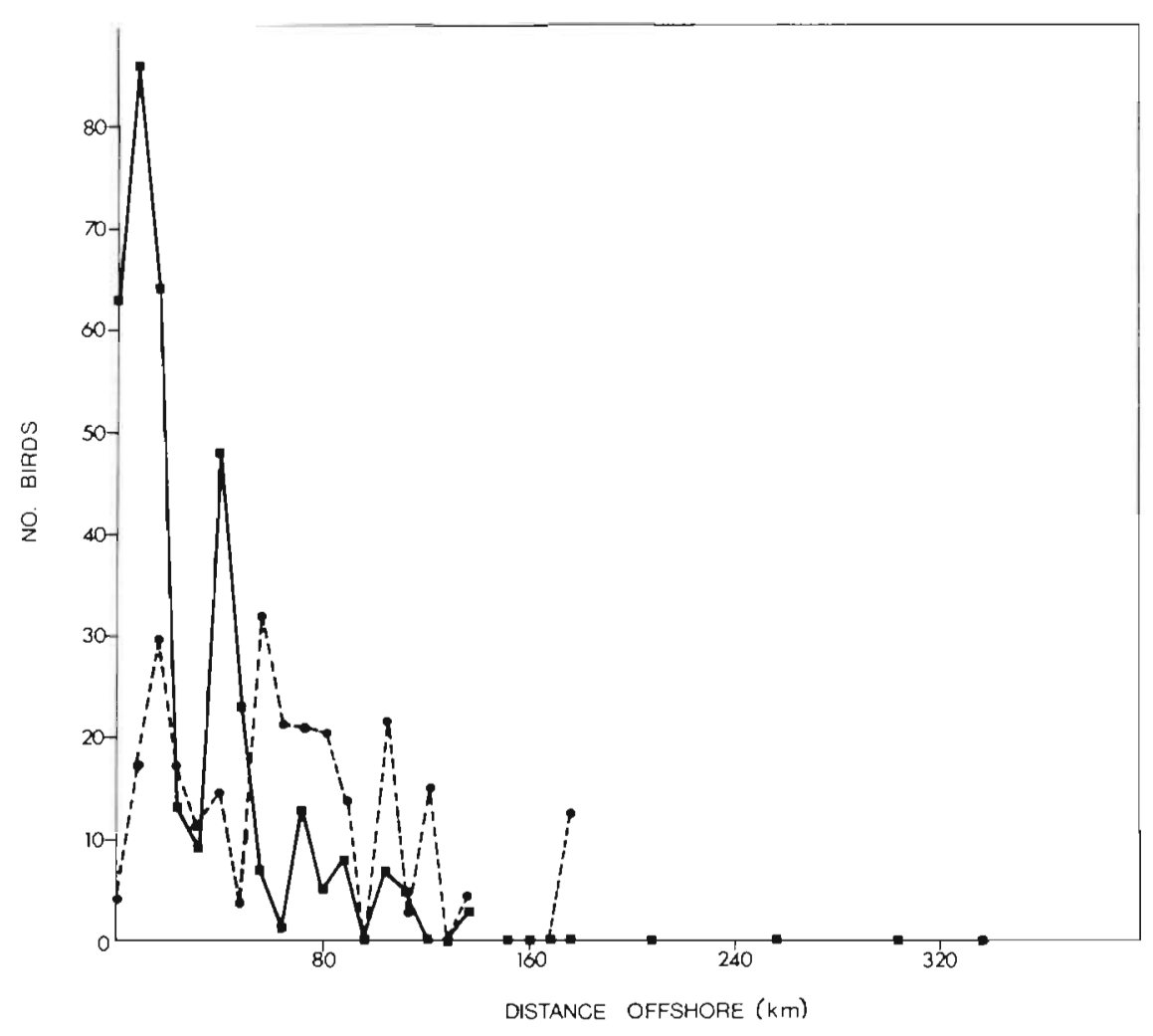

Fig. 8. Mean abundance (number of individuals) of all pisclvores (continuous line) and squid-eaters (broken line) in seabird assemblages according to distance from nearest land in the southern sector of the Benguela Current region

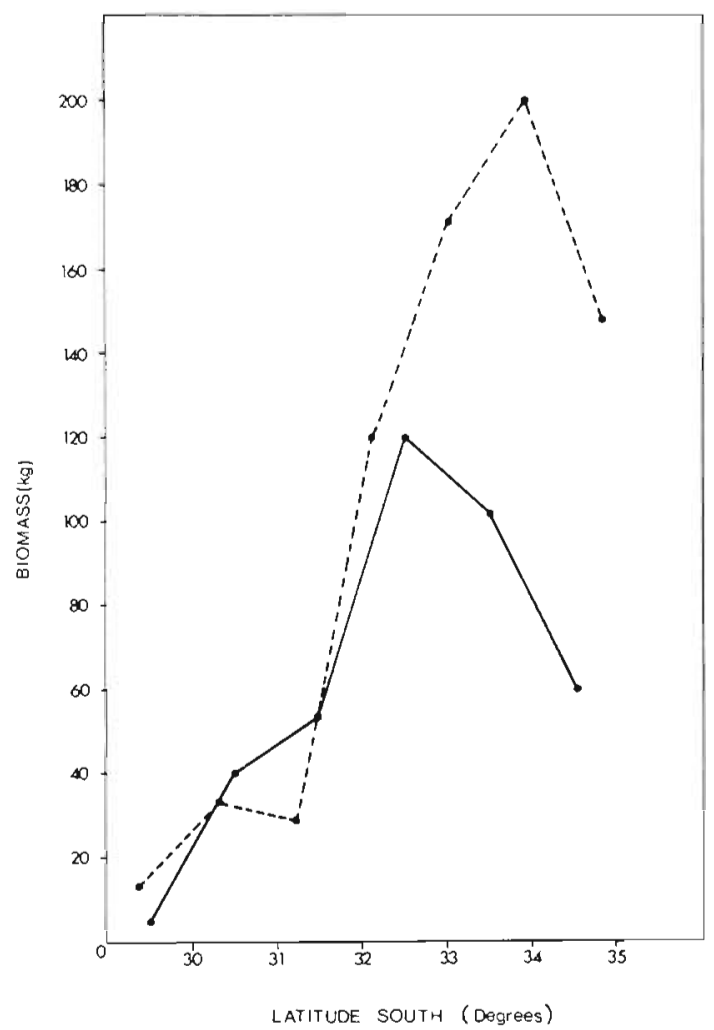

Fig. 9. Mean biomass of seabird assemblages according to latitude. Continuous and broken lines represent observations made in summer and winter respectively

Table 5. Coefficients of correlation ( $r$ ) between feeding-method groups in seabird assemblages in the southern sector of the Benguela Current region

\begin{tabular}{|c|c|c|c|c|c|c|}
\hline Feeding method & $\begin{array}{c}\text { Surface } \\
\text { seizing/ } \\
\text { scavenging }\end{array}$ & $\begin{array}{c}\text { Surface } \\
\text { filtering }\end{array}$ & Plunging & $\begin{array}{l}\text { Pursuit } \\
\text { plunging/ } \\
\text { diving }\end{array}$ & $\begin{array}{l}\text { Dipping/ } \\
\text { pattering }\end{array}$ & Piracy \\
\hline Surface filtering & .014 & 1.000 & & & & \\
\hline Plunging & 107 & .016 & 1.000 & & & \\
\hline Pursuit plunging/diving & .091 & .014 & 102 & 1.000 & & \\
\hline Dipping/pattering & .144 & .029 & .025 & .010 & 1.000 & \\
\hline Piracy & 127 & .014 & 171 & 108 & 117 & 1.000 \\
\hline Bottom feeding & .106 & .010 & .007 & .032 & .032 & .003 \\
\hline
\end{tabular}

\section{DISCUSSION}

The seabird community of the southern sector of the Benguela Current region appears to be typical of continental-shelf avian communities studied elsewhere. Neritic-zone avifaunas are notable for their mixedspecies assemblages, and relatively high species richness and abundance, particularly in regions of high biological productivity. Pelagic seabird communities off California consist of 1-10 species (Ainley, 1976), and the offshore communities in Argentina are charac- terized by 6-13 species involving 50-900 individuals (in mixed-species assemblages) per observation station (Cooke and Mills, 1972; Jehl, 1974). The structure of these communities undergoes seasonal changes, reflecting movements of visiting species breeding in distant oceanic regions, as is the case in the Benguela Current region

The separation of guilds and individual species in time, space and diet contributes to the maintenance of a relatively diverse avifauna in the Benguela Current region (Cooper and Dowle, 1976). Our analysis further 
suggests that a heavy, localized impact by top-order predatory seabirds on their prey in summer (the availability of fish stocks was reduced seasonally during the 1950's [Davies, 1955]) is relieved by a seasonal shift in the geographical focus of the predators, much as Jehl (1974) observed off South America. The piscivores and the squid-eating species (which are present mainly as seasonal visitors) attain peaks in abundance and biomass in winter, declining before the increase in plankton feeders and omnivores. These seasonal changes in the structure of the seabird community probably contribute to its homeostasis. However, the extent (if any) of spatial and temporal separation as a consequence of competition between species for food is not understood, and a proper understanding is necessary if both the ultimate and proximate factors influencing pelagic seabird distribution are to be identified clearly.

It has been suggested that pelagic seabirds are not limited by food when not breeding, since they can range freely (Ashmole, 1971; Diamond, 1978). In this context, Ricklefs and Travis (1980) argue against relying too heavily on competition theory for explaining avian community structures. Morphological constraints on a species' foraging capabilities, and the total number of successful avian morphotypes in a community, will have been selected over a long time and a wide geographical range (especially for seabirds). Since any community study can include only a small part of an animal's evolutionary history, a species' presence at a particular place and time cannot be explained solely by its interactions with proximate physical stimuli and other organisms present. Ricklefs and Travis (1980) propose morphometric analyses as a useful tool in attempts to explain animal community structure. Data on the behaviour and morphology of pelagic seabirds are sparse, yet our study suggests that such an analysis of the Benguela seabird community could be helpful. At present seabird community analyses are hampered by a paucity of detailed information concerning the species diets and feeding habits. (For this reason our guild classification is preliminary, being based on provisional assignments from the literature and unpublished data.)

According to Landres and MacMahon (1980), the most important potential competitive situations occur within guilds, in mixed-species assemblages of foraging birds. Our field observations indicate that sooty shearwaters Puffinus griseus employ subsurface propulsion and take prey not available to the gannet or surface seizers. It is equally evident in the field that albatrosses and gannets, by their size alone, are able to take prey too large for their respective potential competitors, the petrels and shearwaters. Undoubtedly, morphology, seasonal migration and prey availability interact as determinants of seabird community structure. The influence of morphology on the evolution of community structure is to some extent represented in the trophic guild structure of the Benguela community, in that the dominant guilds contain a range of morphotypes and within guilds there is multi-dimensional, spatio-temporal micro-habitat separation. But whether or not the Benguela pelagic seabird community is saturated cannot as yet be determined.

We were unable to derive strong correlations with physical features in attempting to explain the observed non-random pattern of seabird distribution in a relatively small sector of the Benguela Current region. This suggests that the birds' distribution is determined ultimately by prey type and availability, and movements associated with breeding regimes. Prey availability for some species evidently is affected by climate and weather (Siegfried and Crawford, 1978), but whether the birds generally distribute themselves in direct response to their prey and/or the same environmental factors which influence prey availability remains to be seen. Man's overfishing of pelagic fish species in the Benguela Current region during the last 30 y has depressed the resource base for some piscivorous birds, altering the structure of the seabird community (Cooper, in press; Crawford and Shelton, in press). Thus, it is far easier to explain pelagic seabird community structure in terms of its ultimate determinants than to determine the birds short-term motivational drives affecting their distribution. Although seabird distribution is suggestive of randomness, because of the animals' capacity to range over large areas in short periods, proximate factors, including peculiar water masses and weather, probably influence both community structure and distribution when examined over a wider range of oceanic conditions than those included in the southern sector of the Benguela Current region. In our continuing research embracing a wider distribution of seabirds in the Southern Ocean we intend to compare potentially interacting hypotheses, as recommended by Grant and Abbott (1980). We expect to find through juxtaposition of alternative hypotheses, rather than by testing against a null hypothesis of randomness, that the interactive determinants of trophic ecology, physical environment and breeding biology, combine in an hierarchical fashion to shape pelagic seabird community structure.

\section{CONCLUSIONS}

At our present stage of analysis of the pelagic seabird community of the Benguela Current region, it is possible to predict that at any point in time and space a localised neritic seabird assemblage will be domi- 
nated in numbers and biomass by one trophic guild, although individuals from other trophic guilds will be present as well. It is also probable that if the aggregation in question is dominated by squid-eaters or piscivores, the number of species present will be fewer than if the aggregation is dominated by omnivores or planktivores. Avian species richness and abundance in the Benguela Current region are determined mainly by the breeding cycles and foraging needs of the endemic residents and visiting species from the Southern Ocean. The relative success of species and the rein- forcement of their repeated return to southern Africa each season are influenced by their morphology and the stability of the ecosystem (i. e. the selection pressures which operate within guilds, and the annual fluxes in fish and squid stocks, respectively).

Acknowledgements. We are grateful to the Sea Fisheries Institute. the South African National Committee on Oceanographic Research, and the University of Cape Town for financial and logistical assistance. We thank Cdr A. Thomas for helpful advice.

Appendix 1. Principal food-type and feeding-method guilds and body-weights of seabird species occurring commonly in the southern of the Benguela Current region. Food-type and feeding-method classification based on data in Ashmole (1971), Ainley (1977) and unpublished records taken from the Fitz Patrick Institute which also maintains records of bird weights

\begin{tabular}{|c|c|c|c|}
\hline Food type & Feeding method & Species & $\begin{array}{c}\text { Body-weight } \\
(\mathrm{kg})\end{array}$ \\
\hline Plankton & $\begin{array}{l}\text { Dipping \& pattering } \\
\text { Dipping \& pattering } \\
\text { Pursuit diving } \\
\text { Surface filtering } \\
\text { Surface seize/scavenge } \\
\text { Dipping \& pattering }\end{array}$ & $\begin{array}{l}\text { Oceanodroma leucorhoa, Leach's Stormpetrel } \\
\text { Oceanites oceanicus, Wilson's Stormpetrel } \\
\text { Puffinus assimilis, Little Shearwater } \\
\text { Pachyptila spp., Prion } \\
\text { Daption capense, Pintado Petrel } \\
\text { Hydrobates pelagicus, European Stormpetrel }\end{array}$ & $\begin{array}{l}0.05 \\
0.04 \\
0.23 \\
0.15 \\
0.45 \\
0.35\end{array}$ \\
\hline Cephalopods & $\begin{array}{l}\text { Surface seize/scavenge } \\
\text { Surface seize/scavange } \\
\text { Surface seize/scavenge } \\
\text { Surface seize/scavenge } \\
\text { Surface seize/scavenge } \\
\text { Surface seize/scavenge } \\
\text { Surface seize/scavenge } \\
\text { Surface seize/scavenge }\end{array}$ & $\begin{array}{l}\text { Pterodroma macroptera, Greatwinged Petrel } \\
\text { Diomedea cauta, Shy Albatross } \\
\text { Diomedea chlororhynchos, Yellownosed Albatross } \\
\text { Diomedea melanophris, Blackbrowed Albatross } \\
\text { Procellaria cinerea, Grey Petrel } \\
\text { Procellaria aequinoctialis, Whitechinned Petrel } \\
\text { Pterodroma mollis, Softplumaged Petrel } \\
\text { Diomedea exulans, Wandering Albatross }\end{array}$ & $\begin{array}{l}0.58 \\
4.10 \\
2.00 \\
3.50 \\
1.03 \\
1.21 \\
0.31 \\
8.60\end{array}$ \\
\hline Fish & $\begin{array}{l}\text { Bottom feeding } \\
\text { Surface seize/scavenge } \\
\text { Dipping \& pattering } \\
\text { Pursuit diving } \\
\text { Pursuit diving } \\
\text { Dipping \& pattering } \\
\text { Bottom feeding } \\
\text { Pursuit diving } \\
\text { Plunging } \\
\text { Pursuit diving } \\
\text { Dipping \& pattering }\end{array}$ & $\begin{array}{l}\text { Phalacrocorax carbo, White-breasted Cormorant } \\
\text { Calonectris diomedea, Cory's Shearwater } \\
\text { Sterna viftata, Antarctic Tern } \\
\text { Puffinus gravis, Great Shearwater } \\
\text { Puffinus griseus, Sooty Shearwater } \\
\text { Sterna hirundo, Common Tern } \\
\text { Phalacrocorax neglectus, Bank Cormorant } \\
\text { Phalacrocorax capensis, Cape Cormorant } \\
\text { Morus capensis, Cape Gannet } \\
\text { Spheniscus demersus, Jackass Penguin } \\
\text { Sterna paradisaea, Arctic Tern }\end{array}$ & $\begin{array}{l}2.50 \\
0.96 \\
0.14 \\
0.95 \\
0.79 \\
0.10 \\
1.95 \\
1.28 \\
2.69 \\
2.99 \\
0.13\end{array}$ \\
\hline Mixed & $\begin{array}{l}\text { Piracy } \\
\text { Surface seize/scavenge } \\
\text { Dipping \& pattering } \\
\text { Piracy } \\
\text { Piracy } \\
\text { Piracy } \\
\text { Piracy }\end{array}$ & $\begin{array}{l}\text { Stercorarius Jongicaudus, Longtalled Skua } \\
\text { Macronectes spp., Giant Petrel } \\
\text { Larus hartlaubij, Hartlaub's Gull } \\
\text { Larus domunicanus, Kelp Gull } \\
\text { Stercorarius parasiticus, Arctıc Skua } \\
\text { Stercorarius pomarnus, Pomarine Skua } \\
\text { Catharacta antarctica, Antarctic Skua }\end{array}$ & $\begin{array}{l}0.29 \\
4.65 \\
0.30 \\
1.00 \\
0.53 \\
0.67 \\
1.63\end{array}$ \\
\hline
\end{tabular}

\section{LITERATURE CITED}

Ainley, D. G. $\{1976\}$. The occurrence of seabirds in the coastal region of California. Western Birds 7 (2): 33-68

Ainley, D. G. (1977). Feeding methods in seabirds: A comparison of polar and tropical nesting communities in the eastern Pacific Ocean. In: Llano, G. A. (ed.) Adaptations within Antarctic ecosystems. Smithsontan Institute, Washington, D. C., pp. 669-685

Ashmole, H. P. (1971). Seabird ecology and the marine environment. In: Farner, D. S., King, A. (eds) Avian biology (I). Academic Press, New York, pp. 224-271

Bang, N. D. (1971). The southern Benguela Current region in February, 1966. Part 2 - Bathythermography and air-sea interactions. Deep Sea Res. 18: 209-224 
Brooke, R. K. (in press). The place of South Africa in the world of seabirds and other marine animals. In: Cooper, J. (ed.) Proc. symp. birds of sea and shore, Cape Town, 1979. African Seabird Group, Cape Town

Cooke, F., Mills, E. L. (1972). Summer distributıon of pelagic birds off the coast of Argentina. Ibis 114: 245-251

Cooper, J. (in press). Changes in resource division among four breeding seabirds in the Benguela upwelling system. 5th Pan. Afr Orn. Congr.

Cooper, J., Dowle, J. E. (1976). Seasonal and spatial distribution of some Procellariiforme seabirds in Southern African waters. Ardea 64: 72-79

Crawford, R. J. M., Shelton, P. A. (in press). Population trends for some southern African seabirds relative to fish availability. In: Cooper, J. (ed.) Proc. symp. birds of sea and shore, Cape Town, 1979. African Seabird Group, Cape Town

Cushing, D. H. (1971). Upwelling and the production of fish. Adv. mar. Biol. 9: 255-334

Davies, D. H. (1955). Bird predators, 1953-54. Div. of Sea Fish Invest. Rep. 18: 1-32

Diamond, A. W. (1978). Feeding strategies and population size in tropical seabirds. Am. Nat. 112 (983) : 215-223

Emery, K. D., Milliman, J. D., Uchupi, E. (1973). Physical properties and suspended matter of surface waters in the southeastern Atlantic Ocean. J. sedim. Petrol. 43 (3): 822-837

Grant, P. R., Abbott, I. (1980). Interspecific competition, island biogeography and null hypotheses. Evolution 34 (2): 332-341

Hart, T. J., Currie, R. I. (1960). Discovery report VXXXI: The Benguela Current. Cambridge University, Cambridge, pp. 123-298
Jehl, J. R. (1974). The distribution and ecology of marine birds over the continental shelf of Argentina in winter Trans. San Diego Soc. Nat. Hist. 17 (16): 217-234

Kessel, B. (1979). Avian habitat classification for Alaska. Murrelet 60 (1): $86-94$

Landres, P. B., MacMahon, J. A. (1980). Guilds and community organisation: Analysis of an oak woodland avifauna in Sonora, Mexico. Auk. 97: 351-365

Marchand, J. M. (1952). Annual Report for the year ended 1951, South African Division of Sea Fisheries, Cape Town.

Pocklington, R. (1979). An oceanographic interpretation of seabird distributions in the Indian Ocean. Mar Biol. 51: 9-21

Ricklefs, R. E., Travis, J. (1980). A morphological approach to the study of avian community organisation. Auk 97 (2): $321-338$

Siegfried, W R., Crawford, R. J. M. (1978). Jackass Penguins, eggs and guano: Diminishing resources at Dassen Island S. A. J. Sci. $74: 389-390$

Summerhayes, C. P. (1976). Seabird observations between Dakar and Cape Town, December, 1973-January, 1974 Ostrich 47: 55-58

Summerhayes, C. P., Hofmeyer, P. K., Rioux, H. (1974). Seabirds off the southwestern coast of Africa. Ostrich 45: $88-109$

Sverdrup, H. U., Johnson, M. W., Fleming, R. H. (1942). The oceans: Their physics, chemistry and general biology, Prentice Hall, New York

Watson, G. E. (1975). Birds of the Antarctic and Subantarctic, American Geophysical Union, Washington, D. C 